Images in...

\title{
Primary cutaneous cryptococcosis in a liver transplant recipient
}

\author{
Tristan Ferry, ${ }^{1,2,3}$ Doriane Moos, ${ }^{1,2,4}$ Sylvie Radenne, ${ }^{1,2,5}$ Anne-Lise Bienvenu, ${ }^{1,2,6}$ Jean Kanitakis ${ }^{1,2,7}$
}

${ }^{1}$ Hospices Civils de Lyon, Lyon, France;

2Université Claude Bernard Lyon 1, Lyon, France:

${ }^{3}$ Service de Maladies Infectieuses et Tropicales, Hôpital de la Croix-Rousse, Lyon, France;

${ }^{4}$ Service de Dermatologie, Hôpital Edouard Herriot, Lyon, France;

${ }^{5}$ Service d'Hépatologie et Transplantation Hépatique, Hôpital de la Croix-Rousse, Lyon, France;

${ }^{6}$ Lab. de Mycologie Médicale, Hôpital de la Croix-Rousse, Lyon, France;

${ }^{7}$ Lab. d'Anatomie Pathologique, Hôpital Edouard Herriot, Lyon, France

Correspondence toDr Tristan Ferry, tristan.ferry@univ-lyon1.fr

\section{DESCRIPTION}

A 31-year-old Caucasian office worker who had received a liver transplanted 1 year earlier consulted for a painful ulcer located on the medial face of the right elbow (figure 1). Four months before, he fell while skiing (without direct cutaneous exposure) and developed a haematoma on the right elbow that never healed but fistulised and ulcerated. The lesion was solitary and there were no clinical signs of dissemination. White blood cell count and $\mathrm{C}$ reactive protein were within normal levels. Cryptococcal capsular antigen (CCA) was undetectable in serum. Microscopic examination of a skin biopsy specimen showed numerous encapsulated yeast forms amidst a dense dermal inflammatory infiltrate (figure 1). Cultures yielded C. neoformans var. neoformans (serotype D, identified using a monoclonal antibody specific for capsular polysaccharide).

The patient was given fluconazole $(6 \mathrm{mg} / \mathrm{kg} / \mathrm{d}$ following a single loading dose of $12 \mathrm{mg} / \mathrm{kg}$ ) and surgical debridement was performed. Tacrolimus dose was reduced by $50 \%$ because of drug interactions. The OTc-interval remained $<420 \mathrm{~ms}$ and no hepatotoxicity occurred during treatment. Complete healing of the lesion was achieved within four months of treatment.

Primary cutaneous cryptococcosis (PCC) in transplant recipients is usually a localised disease, without evidence for dissemination based on undetectable CCA in serum and negative blood, urine and CSF cultures. PCC is characterised by a solitary lesion, predominantly developing on the upper limbs following a pre-existing skin traumatism due to outdoor hobbies/activities. ${ }^{1} 2$ Unlike disseminated cryptococcosis, most PCC cases are due to Cryptococcus neoformans var. neoformans. ${ }^{1}$ Treatment consists of systemic antifungal therapy with fluconazole, with or without surgical resection. Interactions with immunosuppressive drugs (mainly tacrolimus and ciclosporin) need to be considered. ${ }^{3}$ This treatment is usually effective, provided it is administered for 4 weeks to 4 months. ${ }^{12}$

Acknowledgements The authors acknowledge Institut Pasteur, Unité de Mycologie Moléculaire, Centre National de Référence Mycologie et Antifongiques, Paris, France for serotyping.

Competing interests None.

Patient consent Obtained.
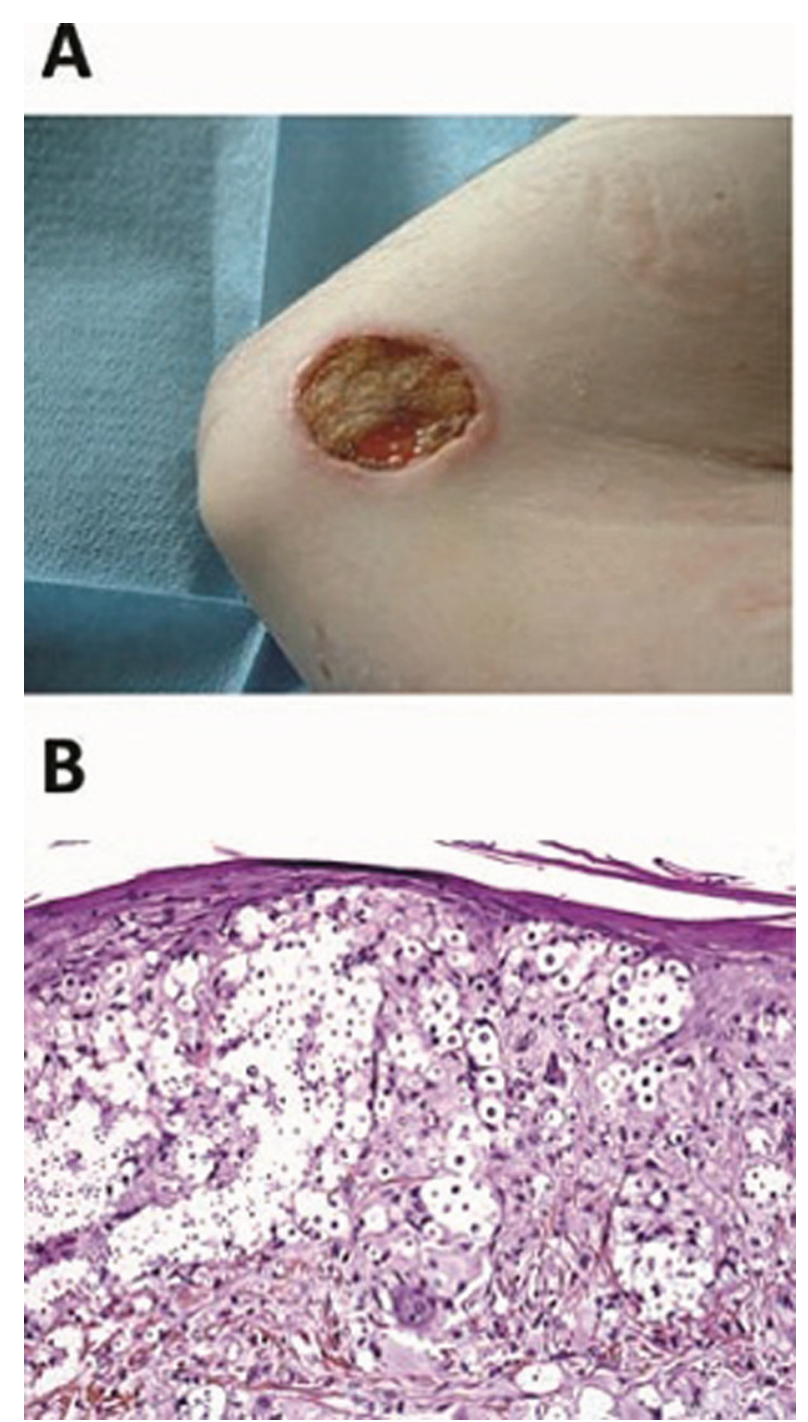

Figure 1 (A) $3.5 \times 2.6 \mathrm{~cm}$ umbilicated, ulcerated lesion is seen on the right medial face of the elbow. (B) Microscopic examination shows multiple cryptococcal organisms within the dermis (haematoxylin-eosin-saffron staining, original magnification, $\times 400)$. 


\section{BMJ Case Reports}

\section{REFERENCES}

1. Neuville S, Dromer F, Morin 0, et al. Primary cutaneous cryptococcosis: a distinct clinical entity. Clin Infect Dis 2003;36:337-47.

2. Sun HY, Alexander BD, Lortholary 0, et al. Cutaneous cryptococcosis in solid organ transplant recipients. Med Mycol 2010;48:785-91.
3. Mahnke CB, Sutton RM, Venkataramanan R, et al. Tacrolimus dosage requirements after initiation of azole antifungal therapy in pediatric thoracic organ transplantation. Pediatr Transplant 2003;7:474-8.

This pdf has been created automatically from the final edited text and images.

Copyright 2011 BMJ Publishing Group. All rights reserved. For permission to reuse any of this content visit http://group.bmj.com/group/rights-licensing/permissions.

BMJ Case Report Fellows may re-use this article for personal use and teaching without any further permission.

Please cite this article as follows (you will need to access the article online to obtain the date of publication).

Ferry T, Moos D, Radenne S, Bienvenu AL, Kanitakis J. Primary cutaneous cryptococcosis in a liver transplant recipient. BMJ Case Reports 2011; 10.1136/bcr.02.2011.3814, date of publication

Become a Fellow of BMJ Case Reports today and you can:

- Submit as many cases as you like

- Enjoy fast sympathetic peer review and rapid publication of accepted articles

- Access all the published articles

- Re-use any of the published material for personal use and teaching without further permission

For information on Institutional Fellowships contact consortiasales@bmjgroup.com

Visit casereports.bmj.com for more articles like this and to become a Fellow 